<原 著 $>$

原発性肝癌腫瘍マーカーとしての glutathione S-transferase の意義 一免疫組織化学的検討一

伊坪真理子 亀田 治男* 田中 垻 石川 智久**

要 旨：肝細胞癌, 胆管細胞癌路よび転移性肝癌において酸性 glutathione S-transferase （GST）と塩基性 GST について兔废組織化学的険索を行なった。 その結果，酸性 GST は大多 数の胆管細胞癌之くに分化型で陽性所見を得たが，はとんどの所細胞癌之半数の転移性肝癌で は陽性所見を得なかった. 塩基性 GST は過半数の肝細胞癌で陽性であったが，その多くは比較 的弱い反応であった，塩基性 GST は正常肝肝細胞では均一な陽性所見示すが，前癌病変 とも考学られている liver cell dysplasia で減弱傾向がみられた，以上ょり，酸性 GST は原発 性肝癌のらち胆管細胞癌の良い免疫組織化学的畽禓マーカーになることが明らかとなった。血 清レベルに反映される可能性より臨休経過の指標としての有用性も示唆された。一方塩基性 GST は隀瘍マーカーとしての意義は小さいが, 肝細胞癌の前癌病変解析などのマーカーになる 可能性が示唆された。

賁引用語：原発性肝癌腫瘍マーカー 酸性 glutathione S-transferase

塩基性 glutathione S-transferase 免疫組織化学

はじめに

Glutathione S-transferase (GST, EC 2, 5, 1, 18) 法生体内に広く分布し，蓧物代謝系酳素の 1 つとして 程々の解害機構に関与する多機能醭素であり，また BSPゃICGなどの有機陰イオンの肝細胞内移送を司 る結合蛋白としても作用する”，最近，癌と酵素偏倚の 観点からGSTが注目されるようになった，GSTは多 くのアインザイムより成り，現在，等電点 $\mathrm{pI} に よ り$ 塩 基性（pI>8.0），中性（pI 7 8)，酸性（pI<7.0）の 3 群2゙k大別されることが多いか，報告者により必ず しる見解の綡一が得られていない，上卜肝には塩基性 GST'が豊富に存在するが, 中性 GST"は特定のヒト

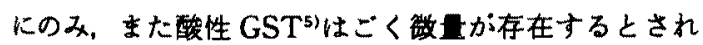
$\tau$ てい.

酸性 GST は胎児肝甲胎盤に曹富に存在するか，胎 盉由来の GST- $\pi^{6}$ が原発性肝癌，胃癌，大腸癌，など 各種悪性董瘍患者血清中で高値を示すことが報告され ている7)。我々は免疫組織化学的に原発性肝癌のらち 胆管細胞癌で GST・ $\pi$ が腫痬マーカーになる可能性を 示した ${ }^{81}$. 一方塩基性 GST であるリガンディンの肝細

“東京慈恵会医科大学第 1 内科

*“同第 1 病理

〈受付日1990年 5 月23日 $>$
胞癌患者血清浱度は多様な変動を示しており，その意 味つけが議論されているッ。そこで今回酸性および塩 基性 GST か，原発性肝癌の腫湯マーカーとしていか なる役割を果たしらるかを明らかにするため，免废組 織化学的怏討を行なったので報告する.

\section{方 法}

1. 材料

原発性肝癌33例（肝細胞癌21例，胆管細胞癌12例） を対象とした，対照として臨床的，形態的に異常を認 めない正常肝 4 例，非特異的肝炎 7 例，5っ血肝 1 例， 肝硬变11例と，さらに転移性肝癌14例（肝外胆管癌 3 例, 胆烡癌 2 例, 胃癌 2 例, 大腸癌 2 例, 膵癌 2 例, 肺癌 2 例。腎癌 1 例）についてて検索した。

死後 5 時間以内の剖搝および手術時に得られた材料 を，ホルマリン固定, バラフィン包埋し， $4 \mu \mathrm{m}$ の薄切 連続切片を作成した。

\section{2. 酸性书よU塩基性 GST の免疫組織化学的梌索}

酸性 GST は抗ヒトGST・ $\pi$ ボリクローナル抗体 （BIOPREP 社製）を，塩基性 GST は抗七ト塩基性 GST ホリクローナル抗体 (BIOPREP 社製)をそれぞ れ 1 次抗体とし, 間接䤃素抗体法 $(A B C$ 法：VECTOR

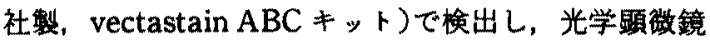
下に観察した，癌部での反応性の判定は酸性 GST で 
は胆管上皮細胞と同程度を，塩基性 GST では正常肝 細胞と同程度を陽性とし，その程度と陽性細胞数の多 宾によって，ほほ認めえないもの(一)，一部の細胞に 認めるすの，あるいは反応は弱いが半数以上の細胞に 認めるものを(土), 半数以上の細胞によく認めるわの を(十), 半数以上の細胞に強く認めるものを(\#) と 区分した。な括細胞癌，胆管細胞癌，転移性肝癌相 互間および肝細胞癌，胆管細胞癌それぞれでの分化度 別の酸性および塩基性 GST の陽性率（土以上を示し た症例の割合)について， $\mathrm{X}^{2}$ 検定を行い有意差を検定 した.

\section{3. 一般光顥的検索}

全例, 型のごとく Hematoxylin-Eosin (H-E) 染色 と Masson trichrom染色を行い，とくに訮硬変では liver cell dysplasia ${ }^{101} に$ 属する肝細胞を，癌部では分 化度を判定した。

\section{成 績}

\section{1. 対照肝組織の GST}

正常肝では酸性 GST は肝細胞に陽性を示さず，門 脈域の胆管上皮細胞や細胆管上皮細胞の細胞質に陽性 を示した（Fig. 1)．その陽性度は必ずしも一様ではな いか，強く反応する細胞が多かった．一方塩基性 GST は肝小葉内にほぼ均一に, 肝細胞の細胞質と一部の核 に陽性を示した (Fig. 2)，胆管上皮細胞にも一部陽性 であった。

非特異的肝炎，5っ血肝では酸性および塩基性 GST は正常肝々ほほ同様の所見を得たが，いわゆる偽胆管 様構造をとる細胞では, 酸性 GST 陽性化と塩基珄 GST 陽性度の減弱傾向をみた(Fig. 3). 肝硬変ではさ

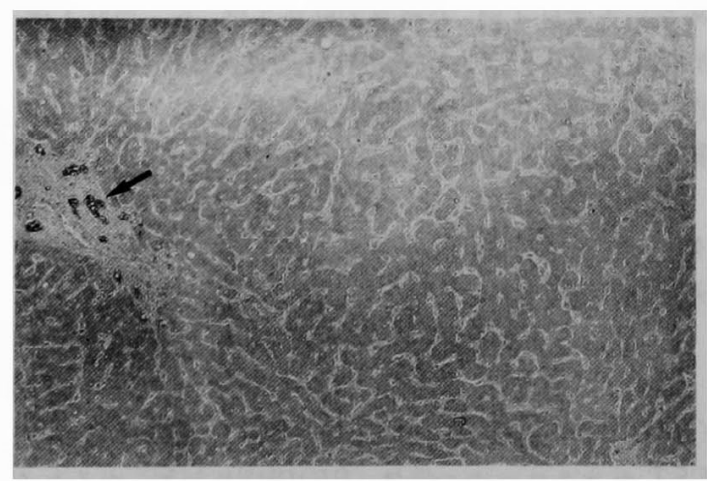

Fig. 1 Immunohistochemical staining of acidic form of GST in normal liver. Positive stain was observed in the cytoplasm of bile duct epithelial cells (arrow) (ABC stain, $\times 25$ ).
らに，塩基性 GST 陽性反応は偽小葉内で不均一な分 布を示すよらになり，偽小葉によっては極めて減弱し ていたまた liver cell dysplasia に属すると考えられ た肝細胞集団では，塩基性 GST が減弱ないし陰性化 する傾向にあった（Fig， 4）。これら肝細胞には酸性 GST が陽性を示すことはなかった。

\section{2. 癌組織の酸性 GST}

原発性肝癌の5ち肝細胞癌21例，胆管細胞癌12例お よび転移性肝癌14例についての酸性 GST の検索結果 をTable 1 に示した. 胆管細胞癌, 転移性肝癌での陽 性率は肝細胞癌に対してそれぞれ有意に高率であった $(p<0.005)$. 前 2 者間には有意差を認めなかった。

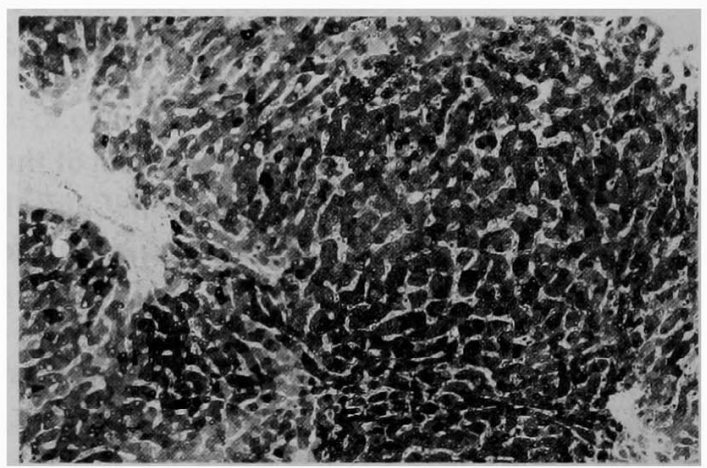

Fig. 2 Immunohistochemical staining of basic form of GST in normal liver. The enzyme was observed uniformly in the cytoplasm and frequently in the nucleus of hepatocytes throughout hepatic lobule ( $A B C$ stain, $\times 25)$.

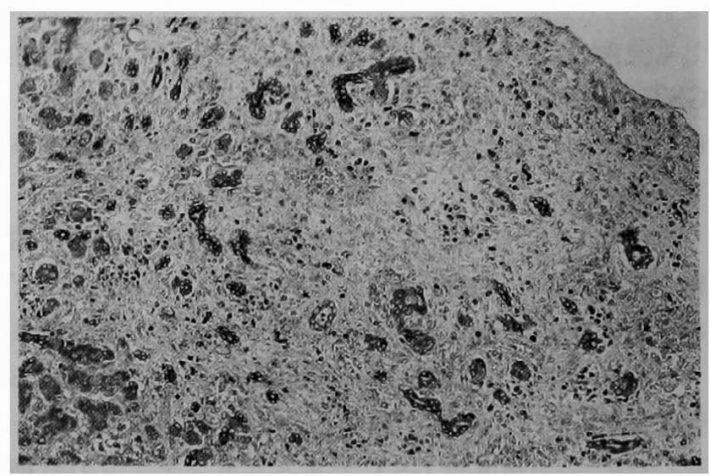

Fig. 3 Immunohistochemical staining of acidic form of GST in so-called pseudobile ductules. Intense staining was observed in the cytoplasm of them (ABC stain, $\times 33$ ). 
Table 1 Immunohistochemical staining of acidic form of GST.

\begin{tabular}{|c|c|c|c|}
\hline & histologic differentiation & staining & no. of cases (\%) \\
\hline \multirow{3}{*}{$\begin{array}{l}\text { Hepatocellular } \\
\text { carcinoma } \\
\text { ( } 21 \text { cases) }\end{array}$} & well differentiated & - & $8(100)$ \\
\hline & moderately differentiated & $\begin{array}{l} \pm \\
-\end{array}$ & $\begin{array}{l}1(16.6) \\
5(83.4)\end{array}$ \\
\hline & poorly differentiated & - & $7(100)$ \\
\hline \multirow{4}{*}{$\begin{array}{l}\text { Cholangiocellular } \\
\text { carcinoma } \\
\text { (12 cases) }\end{array}$} & well differentiated & $\begin{array}{l}+ \\
- \\
\end{array}$ & $\begin{array}{l}3(75) \\
1(25)\end{array}$ \\
\hline & moderately differentiated & $\begin{array}{l}+++ \\
+\sim \pm\end{array}$ & $\begin{array}{l}2(66.7) \\
1(33.3)\end{array}$ \\
\hline & poorly differentiated & $\begin{array}{c}H \sim+ \\
+\sim \pm \\
-\end{array}$ & $\begin{array}{l}2(40) \\
1(20) \\
2(40)\end{array}$ \\
\hline & primary focus & staining & no. of cases $(\%)$ \\
\hline \multirow{7}{*}{$\begin{array}{l}\text { Metastatic } \\
\text { liver } \\
\text { carcinoma } \\
\text { (14 cases) }\end{array}$} & $\begin{array}{l}\text { extrahepatic bile } \\
\text { duct }\end{array}$ & $\begin{array}{l}+\sim+ \\
+\sim \pm\end{array}$ & $\begin{array}{l}1(33.3) \\
2(66.7)\end{array}$ \\
\hline & gall bladder & - & $2(100)$ \\
\hline & stomach & $\begin{array}{l}+ \\
-\end{array}$ & $\begin{array}{l}1(50) \\
1(50)\end{array}$ \\
\hline & colon & $\begin{array}{c}+\sim \pm \\
- \\
\end{array}$ & $\begin{array}{l}1(50) \\
1(50)\end{array}$ \\
\hline & pancreas & $\begin{array}{c}+\sim \pm \\
-\end{array}$ & $\begin{array}{l}1(50) \\
1(50) \\
\end{array}$ \\
\hline & lung & $\begin{array}{l}+ \\
\pm \\
\end{array}$ & $\begin{array}{l}1(50) \\
1(50)\end{array}$ \\
\hline & kidney & - & $1(100)$ \\
\hline
\end{tabular}

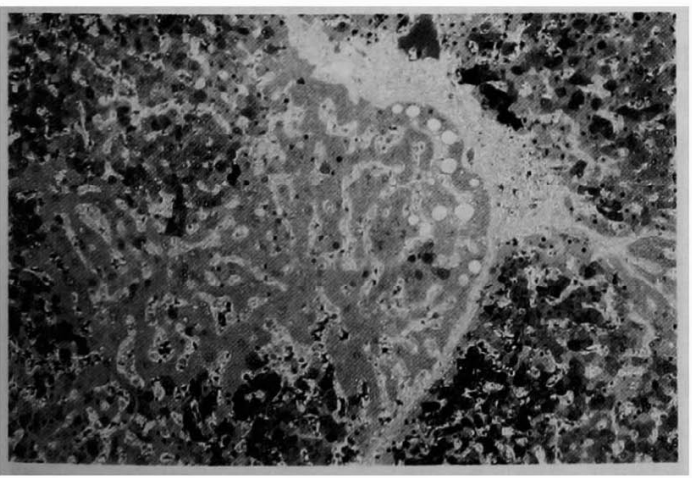

Fig. 4 Immunohistochemical staining of basic form of GST in liver cell dysplasia. The enzyme was hardly observed in the cytoplasm of dysplastic hepatocytes $(A B C$ stain, $\times 33)$.

1) 肝細胞癌

酸性 GST は 1 例のみにごく一部の癌細胞に陽性を
示したが, 残りの20例には明らかな陽性所見は得られ なかった。

\section{2) 胆管細胞癌}

大多数の症例で酸性 GST は明らかに陽性であっ た，有意差は認められなかったが，とくに分化度の高 いものほど，陽性の強さと陽性細胞数が增す傾向に あった (Fig. 5).

\section{3）転移珄肝癌}

酸性 GST は約半数の症例で陽性であった，肝外胆 管癌由来の 3 例ではいずれも陽性を示した (Fig. 6). 陽性度の弱い例でも他缄器癌由来に比へ，陽性細胞か; 多くみられた，他に胃，大腸，膵，肺を原発とする分 化度の高い癌で陽性であった。このらち胃癌および肺 癌由来の各 1 例では陽性細胞が多数みられたが、これ ら以外では一部の癌細胞のみ陽性であった。

\section{3. 癌組織の塩基性 GST}

原発性肝癌のらち肝細胞癌11例と胆管細胞癌12例に 
Table 2 Immunohistochemical staining of basic form of GST.

\begin{tabular}{l|l|c|c}
\hline & histologic differentiation & staining & no. of cases(\%) \\
\hline \multirow{4}{*}{$\begin{array}{l}\text { Hepatocellular } \\
\text { carcinoma } \\
\begin{array}{c}\text { (11 cases) } \\
\end{array}\end{array}$} & well differentiated & $+\sim+$ & $3(75)$ \\
& moderately differentiated & - & $1(25)$ \\
\cline { 2 - 4 } & poorly differentiated & \pm & $2(100)$ \\
\hline \multirow{4}{*}{$\begin{array}{l}\text { Cholangiocellular } \\
\text { carcinoma } \\
\text { (12 cases) }\end{array}$} & well differentiated & - & $2(60)$ \\
& & - & $4(100)$ \\
\cline { 2 - 4 } & moderately differentiated & \pm & $1(33.3)$ \\
\cline { 2 - 4 } & & - & $1(33.3)$ \\
& poorly differentiated & - & $5(100)$ \\
\hline
\end{tabular}

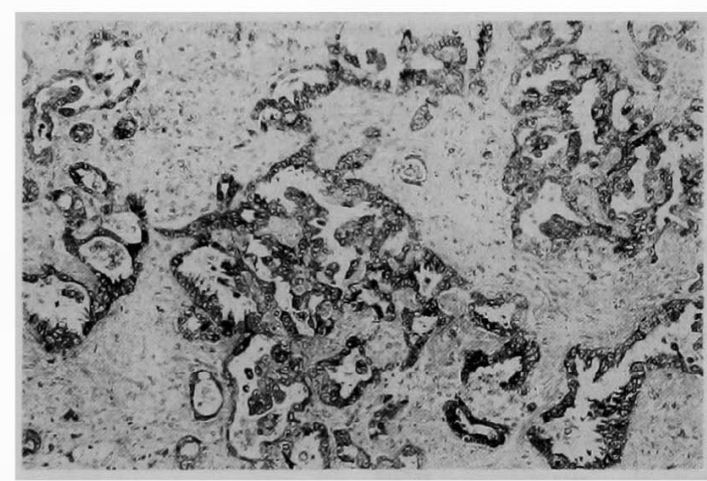

Fig. 5 Immunohistochemical staining of acidic form of GST in well differentiated cholangiocellular carcinoma. Positive stain was observed in the cytoplasm of many cancer cells ( $A B C$ stain, $\times 33$ ).

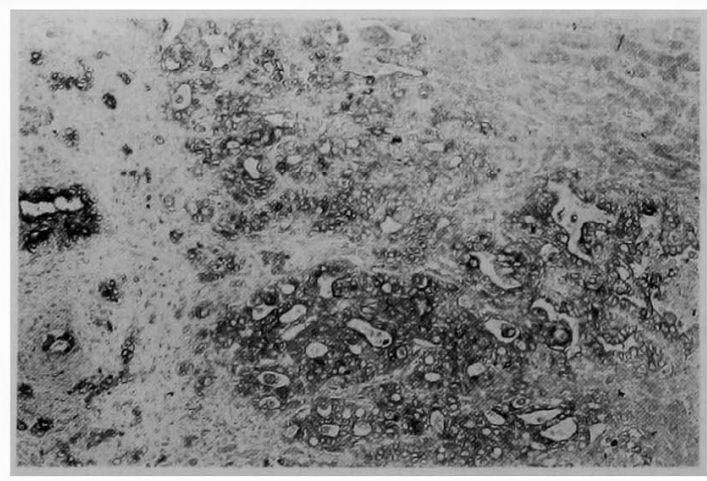

Fig. 6 Immunohistochemical staining of acidic form of GST in metastatic liver carcinoma (primary in extra hepatic bile duct). The enzyme was observed in the cytoplasm of many cancer calls (ABC stain, $\times 33$ ).

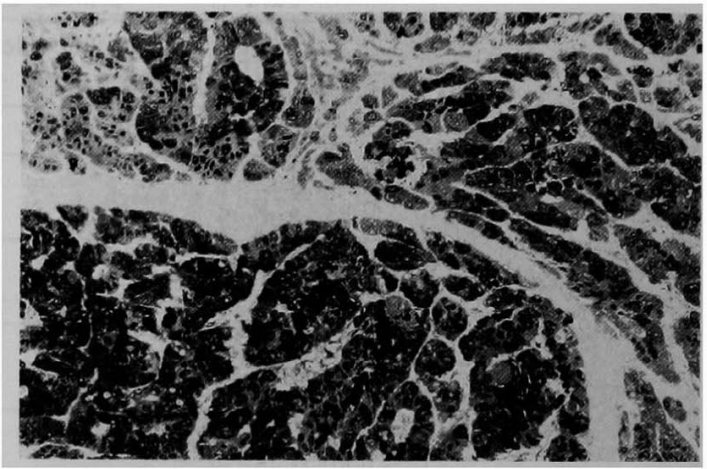

Fig. 7 Immunohistochemical staining of basic form of GST in well differentiated hepatocellular carcinoma. Intense staining was observed in the cytoplasm and in the nucleus of many cancer cells (ABC stain, $\times 33$ ).

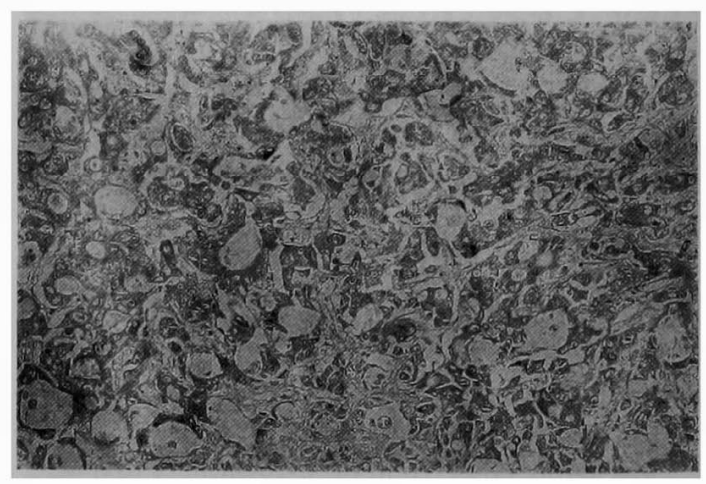

Fig. 8 Immunohistochemical staining of basic form of GST in moderately differentiated cholangiocellular carcinoma. The enzyme was observed faintly in the cytoplasm of many cancer cells $(A B C$ stain, $\times 33)$. 
ついての塩基性 GST の検索結果を Table 2 に示し た。両者の間に陽性率には有意差を認めなかった。

1) 肝細胞癌

塩基性 GST はほぼ2/3の症例で陽性であった。強い 陽性は胞体の豊かな細胞で，索状配列を示す分化度の 高い癌組鐡でみることが多かったが，全体としてはそ の陽性度は弱い傾向にあった (Fig. 7)，分化度による 陽性率には有意差をみなかった。

2）胆管細胞癌

12例中 2 例で塩基性 GST は弱い陽性を示した，陽 性率と分化度には関連を認めなかったが，2 例とも分 化度は中等度であった（Fig. 8).

\section{考 察}

原発性肝癌腫瘍マーカーには $\boldsymbol{\alpha}$-fetoprotein をはじ めいくつかの畽韵烕連物筫が見出されている。しかし 䋓対的なるのはなく，組み合わせることにより癌の検 出率を向上させてきた。 今回検討した GST る, 癌と醉 素㴜倚の観点から尰掦マーカーとしての意義が最近注 目されている.とくに酸性 GSTは、ラット肝化学発癌 過程に招ける前癌・癌病要の良い腫瘄、ーカーとなる ことが確認された GST.P(1) と共通抗原性がある ${ }^{12) こ ~}$ とより，その期待は大きく，各自作製した抗酸性 GST 抗体を用いて研究が進められてきた。 その主体は生化 学的に組轿中や血清中の含量を測定するるのであり， 原発性肝癌や消化管（胃，大腸）由来の転移性肝癌て 増加することが報告された ${ }^{13)}$. しかし組織化学的検索 による組織内局在様式に関するまとまった報告は，

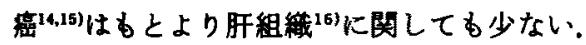

今回の検討に用いた抗 GST 抗体について正常旰組 鶭に括ける反応性の検索を行なったが, 使用した抗 GST- $\pi$ 抗体扰よび抗塩基性 GST 抗体による結果は これまでの諸家9.16.17)の結果と一致しており，本製品の 信頼性は碓かであると考えられた。検索の結果，GST$\pi$ は肝絧胞痁では明らかな陽性所見を得たるのははと んどなく，一方胆管細胞路では12例中 9 例と大多数で 程度の盖はあるが明らかな陽性所見を得た。陽性の強

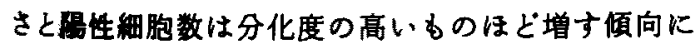
あった。肝細胞癌について，比較的低い陽性率'‘から 50\%の陽性率15)を示す報告があるが，これらと一致し なかった。 その理由としては，偶然我々の対象に陰性 峢が集まった可能性も考えられるが，50\%の陽性率を 示寸艆告では非癌部肝細胞の反応性と同一のるのを (十)と判定しており，我々の判定法，すなから明らか k陽性を示す非㴦部胆管上皮細胞と同程度の反応性を
呈したものを(十）とする，と異なることによるるの かもしれない，酸性 GSTは胎児肝細胞では陽性 ${ }^{17) て ゙ ~}$ あることより，成人では癌化により再び発現する可能 性はあり得るが，今回の検索からは明らかな発現はみ られなかった。

他方胆管細胞癌については，元来肝細胞癌に比べ症 例数が少ないために，多数例での検討は見当らないが， 肝内胆管癌 2 例においてともに陽性であったと報告さ れている ${ }^{14)}$. 今回の12(例の検討により,少なくとも原発 性肝癌では胆管細胞癌, とくに高分化型の良い腫瘍 マーカーになりらることが明らかとなった。したがっ て酸性 GST は正常肝にはごく唡量にしか存在しない ため, 癌の増殖による肝内酸性 GST の増量は血清レ ベルにも反映され，その上昇をむたらすことが期待さ れる，しかし胆管細胞癌のみならず，転移性訮癌です 半数に癌組織の一部に陽珄所見が得られた。 とくに肝 外胆管由来では 3 例とる陽性で，分化度の高いるので はその強さゃ陽性細胞数も增していた。胃, 大腸，膡， 肺からの転移例では分化度の高い癌組織の一部に陽性 所見が得られた，GST- $\pi$ は胃癌，大腸癌，膆癌，肺癌 をはじめ，食道癌，腎癌，乳癌などにも発現すること が知られており、組織および血清レベルでのより詳細 な検討が必要と考えられる. 現在のところ, 酸性 GST が臨床的に畽瘍マーカーとして期待される役割として は，特定の腫埸発見のスクリーニングょりる治療效果 や予後の判定での利用にあると思われ，有力な腫昜 マーカーにそしい胆管細胞癌では大いに期待される.

塩基性 GST は, 肝細胞癌の2/3近くの症例で少なく とも癌組部傤の陽性所見を得た。 とくに分化度の 高いものに陽性を示す傾向にあった．肝稩胞癌の一部 の症例で比較的強い塩基性 GST 陽性所見を得たこと から，とくに高分化型での癌組織含量の増加の可能 性息18)は否定できない.しかし全体的には陽性度が弱い ことより影著な増加は示し難いものと考えられる。 た胆管細胞癌です12例中 2 例に弱いながらも陽性を示 したが, 本来塩基性 GST は肝に豊富に存在し, 肝細胞 にリガンディンの局在が認められるが, 今回もみられ たよらに，ときに成人やまた胎児で胆管上皮細胞にす 陽性を示すことより ${ }^{17}$ ，胆管細胞癌での発現はすり得 るものと思われる。

周知のごとく19）塩基性 GST は非硬変障害肝の肝細 胞では正常肝細胞とほぼ同様な陽性所見を示すのに 対して，肝硬変では陽性度が不均一で減弱化する細胞 も多くみられた。 また，いわゆる liver cell dysplasia 
に属すると考えられる細胞集団の塩基性 GST の陽性 度が减弱ないし陰性化する㑯向がみられた。この事実 は酵素偏倚の観点から興味深い。すなわち，異論はあ るものの dysplasia を前癌病変と考える説 ${ }^{10,20)}$ がある か，肝細胞癌に怙けると同様に塩基性 GST の反応性 の多様な変化，とくに減弱化がみられたことはその傍

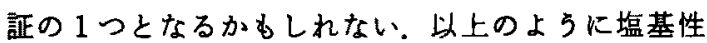
GST については臨床上利用できる隀掦マーカーとし ての意義は小さいものと思われるが，肝細胞癌の発癌 過程, 前癌病変の解析に有用なマーカーとなる可能性 が示唆され、今後さらに検討を要する課題と考えられ る.

\section{まとめ}

酸性および塩基性 GST の原発性肝癌腫暍マーカー としての意義を明らかにする目的で，肝細胞癌21例， 胆管細胞癌12例と正常および障害肝を対照とし，また 転移性肝癌る含めて免疫組織化学的検討を行なった。 その結果,

1）酸性 GST は胆管䋛胞癌，とくに分化型で良い免

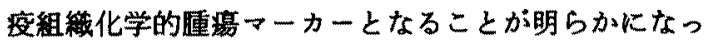
た．血清レベルの上昇として反映される可能泩が推測 され、この場合臨床的にも有用な腫瘍マーカーとなる ものと考えられた。

2）酸性 GST は胆管細胞癌のみならず，肝外胆管癌 由来などの転移性肝癌です免疼組織化学的に陽性所見 を示しらるため，畽場発見の手がかりとしてよりる， 有力な腫瘍マーカーにそしい胆管細胞癌では，治療効 果や予後の指標として有用と考皇る。

3）塩基性 GST は原発性肝癌腫瘄マーカーとして の臨床上の意義は小さいののと思われるが，前癌病変 とも考えられている liver cell dysplasiaで反応性の 変化がみられることょり，癌と䤃素偏倚の観点から， 前癌病変の解析などのマーカーとしての有用性が示唆 された。

本論文の要旨の一部は第76回日本消化器病学会総会で発 表した。なお本研究の一部は文部省科学研究费一般研究 C （策題番号02670322）助成金で行なった。

\section{女颙}

1) Kaplowitz N: Physiological significance of glutathione S-transferases. Am J Physiol 239: G439-G444, 1980

2) Mannervik $B$ : The isozymes of glutathione transferase. Adv Enzymol $57: 357-417,1985$
3) Kamisaka K, Habig WH, Ketley JN, et al: Multiple forms of human glutathione $\mathrm{S}$. transferase and their affinity for bilirubin. Eur J Biochem 60 : 153-161, 1975

4) Warholm M, Guthenberg C, Mannervik B : Molecular and catalytic properties of glutathione transferase $\mu$ form human liver: An enzyme efficiently conjugating epoxides. Biochemistry $22: 3610-3617,1983$

5) Awasthi $Y C$, Dao DD, Saneto RP: Interrelationship between anionic forms of glutathione S-transferases of human liver. Biochem J $191: 1-10,1980$

6) Guthenberg C, Akerfeldt K, Mannervik B : Purification of glutathione S-transferase from human placenta. Acta Chem Scand B33 : 595 $-596,1979$

7）丸山 裕, 新津洋司郎, 高橋康雄, 他：ヒト anionic glutathione S-transferase $の$ radioimmunoassay と消化器悪性畽瘄患者における診断的意義。日消 誌 $84: 268-275,1987$

8）伊坪真理子，电田治男，田中 貢：Glutathione

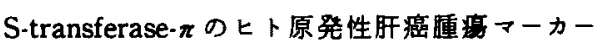
としての意義一免度組織化学的検討一. 肝䁧 30 ： 602, 1989

9) Sherman M, Campbell JAH, Titmuss SA, et al : Glutathione S-transferase in human hepatocellular carcinoma. Hepayology $3: 170-176,1983$

10) Anthony PP, Vogel CL, Barker LF : Liver cell dysplasia: A premalignant condition. J Clin Path $26: 217-223,1973$

11) Sato $K$, Kitahara $A$, Satoh $K$, et al: The placental form glutathione $\mathrm{S}$-transferase as a new marker protein for preneoplasia in rat chemical hepatocarcinogenesis. Gann 75: 199 $-202,1984$

12) Mannervik B, Alin $P$, Guthenberg $C$, et al: Identification of three classes of cytosolic glutathione transferase common to several mammalian species : Correlation between structural data and enzymatic properties. Proc Natl Acad Sci USA 82 : 7202-7206, 1985

13) Soma $Y$, Satoh $K$, Sato $K$ : Purification and subunit-structural and immunological characterization of five glutathione S-transferases in human liver, and the acidic form as a hepatic 
tumor marker. Biochim Biophys Acta $869: 247$ $-258,1986$

14) 水元一博, 堤 雅弘, 牧野刷緒, 他 : Glutathione S-transferase $\pi$ form (GST・ $\pi$ )を用いたヒト肝胆 膵領域癌の免疫組的化学的梌索. 第 45 回日本癌学 会総会記事，1986，p469

15）荻野景規，坂井田功，问 紳雨，他：Glutathione S-transferase $\pi$ の肝細胞癌における免疫組䋨化 学的検討。肝践 $27: 1439-1443,1986$

16) 安部井誠人, 田中直見, 大营俊明, 他：七上肝 glutathione S-transferase アインザイムの免度生 化学的性状と肝組織局在の检討. 日消誌 86 : 2728-2734, 1989
17) Hiley C, Fryer A, Bell J, et al: The human glutathione S-transferases. Biochem J $254: 255$ $-259,1988$

18）広瀬信夫, 南雲晃彦, 船冨 等, 他：七卜肝組織中 での Y蛋白およびりガンディンについて，癌の臨 床 $31: 1247-1252,1985$

19）在伯日出贵：正常および硬变肝における glutathione S-transferase の兔疫組織化学的検討. 肝臓 30 : 734-742, 1989

20) Roncalli $M$, Borzio $M$, Brando $B$, et al : Abnormal DNA content in liver-cell dysplasia : A flow cytometric study. Int J Cancer $44: 204$ $-207,1989$

\title{
Immunohistochemical study of glutathione S-transferases on primary liver carcinoma
}

\author{
Mariko Itsubo, Haruo Kameda*, Mitsugu Tanaka and Tomohisa IshiKaWA**
}

Immunohistochemical localization of acidic and basic form of human glutathione S-transfeases (GST) in hepatocellular carcinoma, cholangiocellular carcinoma and metastatic liver carcinoma was studied. Acidic form of GST was detected within cancer cells in most cases of cholangiocellular carcinoma, especially in differentiated type, although it was detected in almost none of hepatocellular carcinoma and in half the number of metastatic liver carcinoma. Basic form of GST was detected within cancer cells in majority of cases of hepatocellular carcinoma with relatively weak staining except some of them. Occasionally basic form of GST was hardly detected within dysplastic hepatocytes (liver cell dysplasia) although it was homogeneously stained in normal hepatocytes.

These results suggest that acidic form of GST could be not only an excellent immunohistochemical marker of cholangiocellular carcinoma but an useful marker of clinical course on cholangiocellular carcinoma supposing positive staining in cancer cells results in elevation of it's serum level. On the other hand, basic form of GST might be an useful marker of study on preneoplastic lesions of hepatocellular carcinoma.

\footnotetext{
* The First Department of Internal Medicine, The Jikei University School of Medicine (Tokyo)

** The First Department of Pathology, The Jikei University School of Medicine (Tokyo)
} 